\title{
Airborne measurements of trace gas and aerosol particle emissions from biomass burning in Amazonia
}

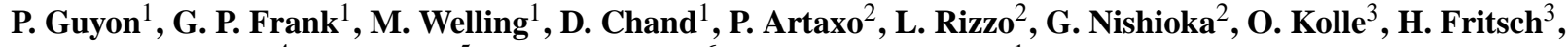 \\ M. A. F. Silva Dias ${ }^{4}$, L. V. Gatti ${ }^{5}$, A. M. Cordova ${ }^{6}$, and M. O. Andreae ${ }^{1}$ \\ ${ }^{1}$ Max Planck Institute for Chemistry, Department of Biogeochemistry, Mainz, Germany \\ ${ }^{2}$ Institute of Physics, University of São Paulo, São Paulo, Brazil \\ ${ }^{3}$ Max Planck Institute for Biogeochemistry, Jena, Germany \\ ${ }^{4}$ Atmospheric Sciences Department, IAG, University of São Paulo, São Paulo, Brazil \\ ${ }^{5}$ Divisão de Química Ambiental, Laboratório de Química Atmosférica, IPEN, São Paulo, Brazil \\ ${ }^{6}$ Center for Advanced Studies in Arid Zones (CEAZA), La Serena, Chile
}

Received: 14 February 2005 - Published in Atmos. Chem. Phys. Discuss.: 9 May 2005

Revised: 24 October 2005 - Accepted: 27 October 2005 - Published: 8 November 2005

\begin{abstract}
As part of the LBA-SMOCC (Large-Scale Biosphere-Atmosphere Experiment in Amazonia - Smoke, Aerosols, Clouds, Rainfall, and Climate) 2002 campaign, we studied the emission of carbon monoxide (CO), carbon dioxide $\left(\mathrm{CO}_{2}\right)$, and aerosol particles from Amazonian deforestation fires using an instrumented aircraft. Emission ratios for aerosol number $(\mathrm{CN})$ relative to $\mathrm{CO}\left(\mathrm{ER}_{\mathrm{CN} / \mathrm{CO}}\right)$ fell in the range $14-32 \mathrm{~cm}^{-3} \mathrm{ppb}^{-1}$ in most of the investigated smoke plumes. Particle number emission ratios have to our knowledge not been previously measured in tropical deforestation fires, but our results are in agreement with values usually found from tropical savanna fires. The number of particles emitted per amount biomass burned was found to be dependent on the fire conditions (combustion efficiency). Variability in $\mathrm{ER}_{\mathrm{CN} / \mathrm{CO}}$ between fires was similar to the variability caused by variations in combustion behavior within each individual fire. This was confirmed by observations of CO-to$\mathrm{CO}_{2}$ emission ratios $\left(\mathrm{ER}_{\mathrm{CO} / \mathrm{CO}_{2}}\right)$, which stretched across the same wide range of values for individual fires as for all the fires observed during the sampling campaign, reflecting the fact that flaming and smoldering phases are present simultaneously in deforestation fires. Emission factors (EF) for CO and aerosol particles were computed and a correction was applied for the residual smoldering combustion (RSC) fraction of emissions that are not sampled by the aircraft, which increased the EF by a factor of 1.5-2.1. Vertical transport of smoke from the boundary layer (BL) to the cloud detrainment layer (CDL) and the free troposphere (FT) was found
\end{abstract}

Correspondence to: $\mathrm{M}$. O. Andreae

(andreae@mpch-mainz.mpg.de) to be a very common phenomenon. We observed a $20 \%$ loss in particle number as a result of this vertical transport and subsequent cloud processing, attributable to in-cloud coagulation. This small loss fraction suggests that this mode of transport is very efficient in terms of particle numbers and occurs mostly via non-precipitating clouds. The detrained aerosol particles released in the CDL and FT were larger than in the unprocessed smoke, mostly due to coagulation and secondary growth, and therefore more efficient at scattering radiation and nucleating cloud droplets. This process may have significant atmospheric implications on a regional and larger scale.

\section{Introduction}

Biomass burning, particularly in the tropics, is a major source of atmospheric trace gases and particles (Artaxo et al., 1998; Andreae and Merlet, 2001). The Amazon Basin is the world's largest rain forest area, containing approximately one quarter of all tropical rainforests, and is subject to one of the highest deforestation rates in the world (Gash et al., 1996; Artaxo et al., 2002). Of the ca. $80 \%$ of the global burning activity taking place in the tropics, one third occurs in South America alone (Liousse et al., 2004). Figure 1a shows the annual deforestation rates for the Amazon region from 1977-2004, which has been increasing over the past 9 years. A 50\% increase in the deforested area was observed over the last 6 years, reaching a level of about $25000 \mathrm{~km}^{2}$ per year in 2003 and 2004. Figure $1 \mathrm{~b}$ shows the number of forest fires detected by the NOAA12 satellite from 1999 to 2004 in

(C) 2005 Author(s). This work is licensed under a Creative Commons License. 

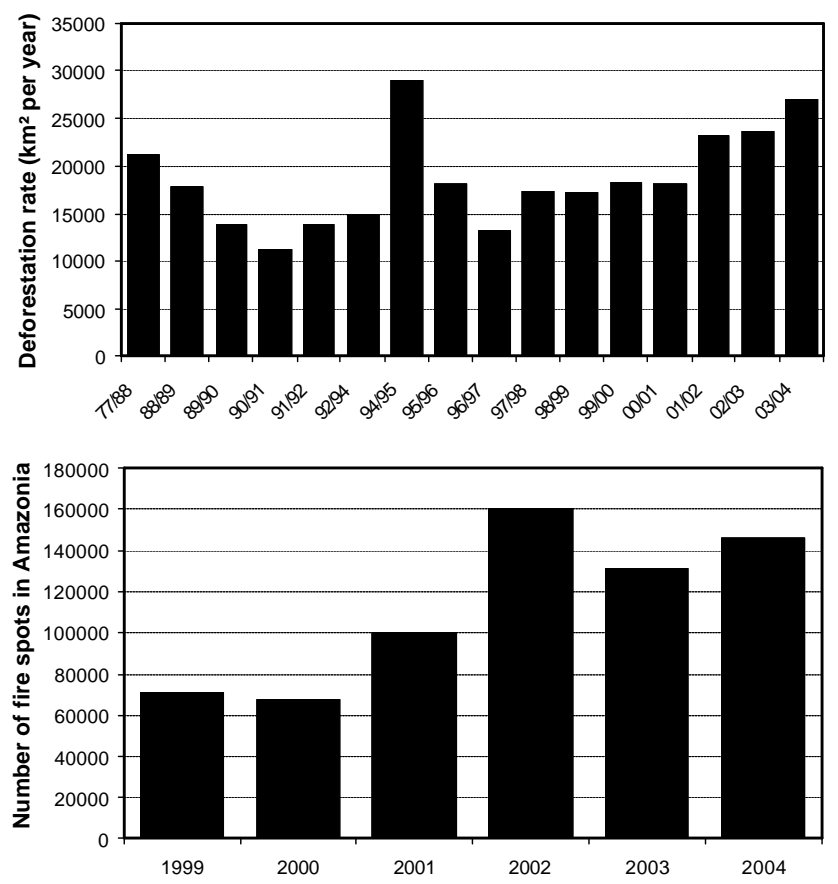

Fig. 1. (a) Deforestation rate in $\mathrm{km}^{2}$ per year for the Amazon region from 1977-2004 as observed by Landsat image analysis. Data kindly provided by the Instituto Nacional de Pesquisas Espaciais (INPE), Saõ Paulo, Brazil. (b) Number of fire spots detected in Amazonia from 1999 to 2004 using the AVHRR (Advanced very high resolution radiometer) NOAA-12 satellite. Data kindly provided by INPE and the Instituto Brasileiro do Meio Ambiente e dos Recursos Naturais Renováveis (IBAMA), Brasília, Brazil.

Amazonia, which has doubled from 2000 to 2004. When entrained into the inter tropical convergence zone (ITCZ) and the Hadley circulation, the biomass-burning emissions from this area can be subjected to long-range transport and affect large areas of the world (Pickering et al., 1996; Andreae et al., 2001; Freitas et al., 2005).

Due to the complex chemistry involved in combustion of natural fuels under ambient conditions, a large number of trace gas species are emitted (e.g., Andreae and Merlet, 2001). However, the large majority of the emissions (> ca. $99 \%$ in mass) consists of carbon dioxide $\left(\mathrm{CO}_{2}\right)$, carbon monoxide (CO) and aerosol particles. $\mathrm{CO}$ is emitted mostly during oxygen-deficient, smoldering combustion, when the oxidation becomes incomplete. On the other hand, flaming fires emit almost exclusively $\mathrm{CO}_{2}$ and oxidized compounds. For this reason, and because of their relatively long atmospheric lifetime (in the order of weeks or longer), $\mathrm{CO}_{2}$ and $\mathrm{CO}$ are often used as biomass-burning tracers and as reference gases for correlation with other chemicals emitted during either the flaming or the smoldering phase of the combustion (Lobert et al., 1991).

Aerosol particles from biomass burning may significantly affect the radiation budget of the Earth directly by absorbing
(Martins et al., 1998) and scattering incoming solar radiation (Procópio et al., 2004), and indirectly by acting as cloud condensation nuclei (CCN) and altering cloud microphysical processes, thereby also influencing the water cycle regionally, and on larger scales (Kaufman et al., 1998). Recent studies have reported very high direct radiative effects from aerosol particles emitted by biomass burning in Amazonia and Africa, with instantaneous surface radiative forcing up to $-300 \mathrm{~W} \mathrm{~m}^{-2}$, and average surface forcing values of around $-30 \mathrm{~W} \mathrm{~m}^{-2}$ (Schafer et al., 2002; Eck et al., 2003; Procópio et al., 2004). The aerosol indirect effects are also large, but difficult to quantify (IPCC, 2001). Measurements of emissions of trace gases and aerosols from biomass burning have been the focus of many in-situ experiments around the world, as well as laboratory studies over the past two decades; for an overview, see Andreae and Merlet (2001). However, these authors also point at the lack of reliable data on the number of particles emitted per amount of biomass burned. Recent studies have filled this gap for savanna fires (e.g., Le Canut et al., 1996; Mauzerall et al., 1998; Andreae et al., 2001; Hobbs et al., 2003), however, for most other types of combustion, and, surprisingly, especially for deforestation fires, available data remain based on estimates from laboratory studies, or are just guessed.

This study presents the first quantitative measurements of the emission rates of aerosol particle numbers from pasture and deforestation fires over the Brazilian Amazon Basin, coupled with data on the emission of the reference gases $\mathrm{CO}$ and $\mathrm{CO}_{2}$. Moreover, we are studying the size distribution of the emitted particles and their scattering ability, thereby contributing to the understanding of the radiative effects of emissions from biomass burning deforestation fires. For the purpose of completeness, we also provide some information on the effects of vertical transport and cloud processing on the emitted particles. However, a detailed discussion of this dataset and its implications will be presented in a future study.

\section{Experimental}

\subsection{Instrumentation and sampling technique}

All the measurements described in this manuscript were obtained aboard the INPE (Instituto Nacional de Pesquisas Espaciais) Bandeirante research aircraft. The aircraft was based in the town of Ji-Paraná $\left(10.88^{\circ} \mathrm{S}, 61.85^{\circ} \mathrm{W}, 235 \mathrm{~m}\right.$ above sea level (a.s.l.)), situated in the state of Rondônia, Brazil, from which most of the 31 research flights started. This region was chosen because it is subject yearly to a high rate of deforestation by burning during the dry season and consequently to high levels of pollution (Guyon et al., 2003). The LBA-SMOCC (Large-Scale Biosphere-Atmosphere Experiment in Amazonia - Smoke, Aerosols, Clouds, Rainfall, and Climate) aircraft campaign took place between 25 September 
and 19 October 2002, encompassing the middle of the smoky dry season and the transition toward the rainy season. For details and overall conditions of the SMOCC 2002 campaign, refer to Andreae et al. (2004).

The aircraft was equipped with a GPS (Garmin), and the altitude and position data were logged on a laptop computer with a $1 \mathrm{~Hz}$ time resolution. Outside air pressure, temperature and humidity were measured using a Vaisala PTB101B pressure transducer, and a Vaisala HMP45D temperature-humidity-probe, respectively, as described by Lloyd et al. (2001). Data were stored with a $1 \mathrm{~Hz}$ acquisition time on a Campbell CR23X data logger/laptop computer combination.

Carbon monoxide (CO) measurements were obtained using an Aero-Laser (AL5002) instrument operating at $1 \mathrm{~Hz}$. Prior to sampling, the air was dried using a Nafion drier. The performance of the instrument was monitored during the flights either every ca. $45 \mathrm{~min}$, or when sampling conditions were to change (e.g., before or after a vertical profile), by conducting zero checks and calibrating the instrument against a standard of known concentration (supplied by White Martins, São Paulo, Brazil). The cylinder gas concentration was determined to be $1574 \pm 33$ ppb by an absolute volumetric technique, which has an absolute uncertainty of 1\% (Brenninkmeijer et al., 2001). Error propagation yields an uncertainty of $2.1 \%$ for our field standard. It is important to note that the data were also corrected for variations in the sensitivity of the instrument resulting from temperature fluctuations of the photomultiplier and aging of the instrument (lamp, optics) over the campaign. After correction and calibration, the difference between flask measurements by the Jena group (flasks collected and analyzed according to Lloyd et al., 2001) and our simultaneous online measurements is $4.5 \pm 3 \%$ (comparison comprised 40 flasks, the online measurements gave the larger values). This agreement can be considered to be very good given the problems of precisely matching the collection periods, storage of flasks and standards, etc.

Carbon dioxide $\left(\mathrm{CO}_{2}\right)$ was measured with a resolution of $1 \mathrm{~Hz}$ using a Licor LI6251 infrared gas analyzer (IRGA). The sampled air was dried with magnesium perchlorate prior to analysis. The air in the closed loop reference circuit was dried with magnesium perchlorate and scrubbed from $\mathrm{CO}_{2}$ using soda-lime pellets. Sampling procedure and data reduction were identical to those described by Lloyd et al. (2001). The precision after applying temperature and pressure corrections and after adjusting the profiles to the flask analysis results was ca. $\pm 0.4 \mathrm{ppm}$.

Aerosol particles were sampled through a $2.5 \mathrm{~mm}$ inner diameter isokinetic inlet, which was mounted on a 1-m long $12.5 \mathrm{~mm}$ stainless steel tube (inner diameter of $10 \mathrm{~mm}$ ). This tube was gently bent to $90^{\circ}$ and fixed below the aircraft. Downstream, the tube was reduced to a $6.3 \mathrm{~mm}$ stainless steel tube (inner diameter of $5.35 \mathrm{~mm}$ ), and aerosols were sampled off this line via a $6.3 \mathrm{~mm}$ stainless steel tube positioned at $90^{\circ}$ with a T-union, producing a cutoff that removed the largest particles. Calculations (Baron, 2001) showed that the sampling from the T-union produced an upper 50\% diameter cut point $\left(D_{50}\right)$ of ca. $300 \mathrm{~nm}$ in a worst-case scenario when the aircraft was flying at the maximum altitude of ca. $4300 \mathrm{~m}$ a.s.l. $\left(P=600 \mathrm{hPa}, T=5^{\circ} \mathrm{C}\right)$. Particles smaller than $500 \mathrm{~nm}$ (and, a fortiori, the $300 \mathrm{~nm}$ particles in the worst case) were neither lost in the bend nor by inertial deposition through the $6.3 \mathrm{~mm}$ line and were sampled with $100 \%$ penetration efficiency by a TSI 3022 condensation particle counter (CPC). Compared to the number size distribution of smoke particles measured simultaneously with a scanning mobility particle sizer (SMPS 3080, TSI), the number concentration of particles ranging ca. $8-300 \mathrm{~nm}$ in diameter measured by the CPC comprised at least $95 \%$ of the total population in number (when the SMPS was measuring over the full accumulation mode from 15 to $414 \mathrm{~nm}$ diameter particles, see below). The CPC data were stored on the datalogger with a resolution of $1 \mathrm{~Hz}$. The sampling flow of our CPC was controlled by a capillary tube, adjusted for pressure and temperature of the sampled air, and the number concentrations corrected using the calculated flow. Particle number concentration and all other extensive aerosol particle parameters reported in this manuscript have been normalized to a standard air pressure $\left(P_{0}\right)$ and temperature $\left(T_{0}\right)$ of $P_{0}=1000 \mathrm{hPa}$, and $T_{0}=25^{\circ} \mathrm{C}$. Overall uncertainties are estimated to be ca. $5 \%$, including the potential effect of some inlet losses of particles in the size range $300-500 \mathrm{~nm}$ at higher altitudes. Due to signal saturation in the datalogger, particle concentration larger than $6999 \mathrm{~cm}^{-3}$ could not be stored. Such concentrations typically occurred in the middle of biomass-burning plumes, so that only the data measured in the outer parts of the plumes could be used to retrieve aerosol number emission ratios (see below). As there is no reason to assume that particles are produced or removed during dilution of the plume with surrounding air, we do not expect that including measurements from the center of the plumes would have changed our results significantly.

Aerosol number size distributions were measured with a SMPS 3080 from TSI for particles ranging $15-414 \mathrm{~nm}$ in diameter (or $15-279 \mathrm{~nm}$ on some of the flights). The particles were collected for $1 \mathrm{~min}$ via an isokinetic inlet (identical to that described above) into a container, from which the instrument sampled. As a complete scan took $1 \mathrm{~min}$, size distributions were obtained with a $2 \mathrm{~min}$ time resolution. Apart from the internal heat of the instrument, no drying was applied to the particles. The size distributions were adjusted for the pressure dependence of the instrument. In the worst case (at the maximum altitude of ca. $4300 \mathrm{~m}$ or $600 \mathrm{hPa}$ ), the corrected diameters were $30 \%$ larger than the original ones.

Aerosol scattering coefficients were obtained using a TSI 3563 nephelometer. Aerosols were sampled in the same fashion as for the CPC measurements, and the data were stored on the datalogger at a 0.5 or $1 \mathrm{~Hz}$ resolution (Chand et al., 2005). 


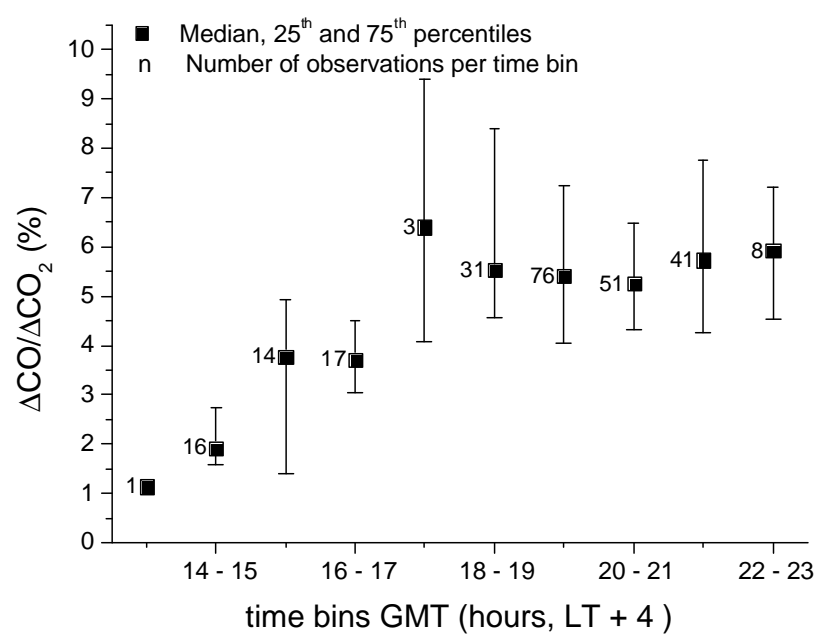

Fig. 2. Diurnal variation of $\mathrm{CO}-$ to- $-\mathrm{CO}_{2}$ emission ratios (in $\% \mathrm{CO}$ per $\mathrm{CO}_{2}$ ) observed from aircraft measurements during the SMOCC 2002 campaign. Given are median values calculated over hourly time bins. The error bars represent the first and third quartiles of the measurements.

Intercomparison of the aircraft instrumentation with ground-based measurements during low altitude fly-bys above the Fazenda Nossa Senhora measurement site (FNS, $10.76^{\circ} \mathrm{S}, 62.32^{\circ} \mathrm{W}, 315 \mathrm{~m}$ a.s.l.), located about $57 \mathrm{~km}$ northwest of Ji-Paraná, showed agreement within $15 \%$ for aerosol scattering, $\mathrm{CN}$, size distribution, and $\mathrm{CO}$ observations.

\subsection{Data analysis}

The various techniques for the calculation of emission ratios (ER) and emission factors (EF) and the associated errors are discussed in detail in Andreae and Merlet (2001) and Le Canut et al. (1996). $E R_{X / Y}$ is the enhancement above background in a biomass-burning plume of a species $X$ over that of a reference species $\mathrm{Y}$ :

$\mathrm{ER}_{\mathrm{X} / \mathrm{Y}}=\frac{\Delta \mathrm{X}}{\Delta \mathrm{Y}}=\frac{\mathrm{X}_{p}-\mathrm{X}_{b}}{\mathrm{Y}_{p}-\mathrm{Y}_{b}}$

where $\Delta \mathrm{X}(\Delta \mathrm{Y})$ is the difference between the concentration of species $\mathrm{X}(\mathrm{Y})$, in the plume $\mathrm{X}_{p}\left(\mathrm{Y}_{p}\right)$, and that in the background air $\mathrm{X}_{b}\left(\mathrm{Y}_{b}\right)$. In this study, ER $\mathrm{X} / \mathrm{Y}$ is defined as the slope of the linear regression of the absolute concentration in species $\mathrm{X}$ of interest on that of the reference species $\mathrm{Y}$ in the plume. The advantage of this method is that it does not necessitate estimating the background concentrations of the species $\mathrm{X}$ and $\mathrm{Y}$ outside of the plume, which can be difficult in a smoke-polluted area.

In the following, we present the ERs of particle number, surface, volume, mass, and scattering coefficients with respect to $\mathrm{CO}$ as well as the $\mathrm{ER}_{\mathrm{CO} / \mathrm{CO}_{2}}$ for Amazonian deforestation and pasture biomass burning plumes. A plume was identified as such when $\Delta \mathrm{CO}$ was at least $100 \mathrm{ppb}$.

\section{Results and discussion}

\subsection{CO-to- $\mathrm{CO}_{2}$ emission ratios $\left(\Delta \mathrm{CO} / \Delta \mathrm{CO}_{2}\right.$ or $\left.\mathrm{ER} \mathrm{CO} / \mathrm{CO}_{2}\right)$}

Figure 2 presents the evolution of $\mathrm{ER}_{\mathrm{CO} / \mathrm{CO}_{2}}$ over the course of the day for all plumes encountered during the SMOCC 2002 campaign when both $\mathrm{CO}$ and $\mathrm{CO}_{2}$ data were available. It is obvious from Fig. 2 that the $\mathrm{ER}_{\mathrm{CO} / \mathrm{CO}_{2}}$ values obtained in the morning hours and until 17:00 UT (13:00 LT) are much lower than those from the afternoon. In the Brazilian Amazon, fires are typically ignited in the late morning or early afternoon, with fire activity peaking around 17:45 UT (Prins et al., 1998). Therefore, the plumes measured in the morning hours are most likely emanating from fires that have been lit on the previous day or before, and they should be in their smoldering phase. Since CO is emitted predominantly during smoldering (incomplete) combustion, the $\mathrm{ER}_{\mathrm{CO} / \mathrm{CO}_{2} \text { for }}$ these fires should be larger than those measured in the afternoon, which is contrary to our results. Moreover, the morning values we observed are actually too low to be truly considered as emission ratios even from flaming fires. A very likely explanation for this phenomenon is that, in the morning hours, $\mathrm{CO}_{2}$-enriched air that accumulated close to the surface during the night due to respiration of the vegetation is entering the convective hot plumes of the fires and is measured by the aircraft together with the fire emissions. Since, in this case, the $\mathrm{CO}_{2}$ from respiration is entrained with the fire plume, it correlates with $\mathrm{CO}$, and does not enter the background $\mathrm{CO}_{2}$ in the linear regression. The background $\mathrm{CO}_{2}$ is taken to be the concentration of $\mathrm{CO}_{2}$ outside of the plume at the altitude of the aircraft, whereas it should be that outside the plume at the ground. In the afternoon, the air is well mixed throughout the boundary layer (BL) and respiration has ceased, so that this phenomenon does not occur. However, it is also likely that a certain number of plumes encountered either in the BL as part of the local haze, in the cloud detrainment layer (CDL), or free troposphere (FT) will keep this biased signature. To our knowledge, this morning bias for ER taking $\mathrm{CO}_{2}$ as a reference gas has not been noticed and published previously, and care should be taken when using $\mathrm{CO}_{2}$ data to derive ER during morning hours. For example, this phenomenon may explain the astonishingly low $\mathrm{ER} / \mathrm{CO} / \mathrm{CO}_{2}$ values ranging $0.9-6.9 \%$ for a grassland/bush smoldering fire observed by Yokelson et al. (2003) in the morning to early afternoon hours of their flight number 1815 . In the following, all data making use of $\mathrm{CO}_{2}$ concentrations that were measured prior to 13:00 LT (17:00 UT) were removed. However, we note here that this phenomenon does not apply to other variables like $\mathrm{CO}$ or aerosols, and these data were kept. For example, Fig. 3 shows that a similar trend is absent in the $\mathrm{ER}_{\mathrm{CN} / \mathrm{CO}}$ over the course of the day. These data are discussed in detail in Sect. 3.2.

Figure 4 presents a frequency plot of the $\mathrm{ER}_{\mathrm{CO} / \mathrm{CO}_{2}}$ obtained for all 163 valid smoke plume transits made during 


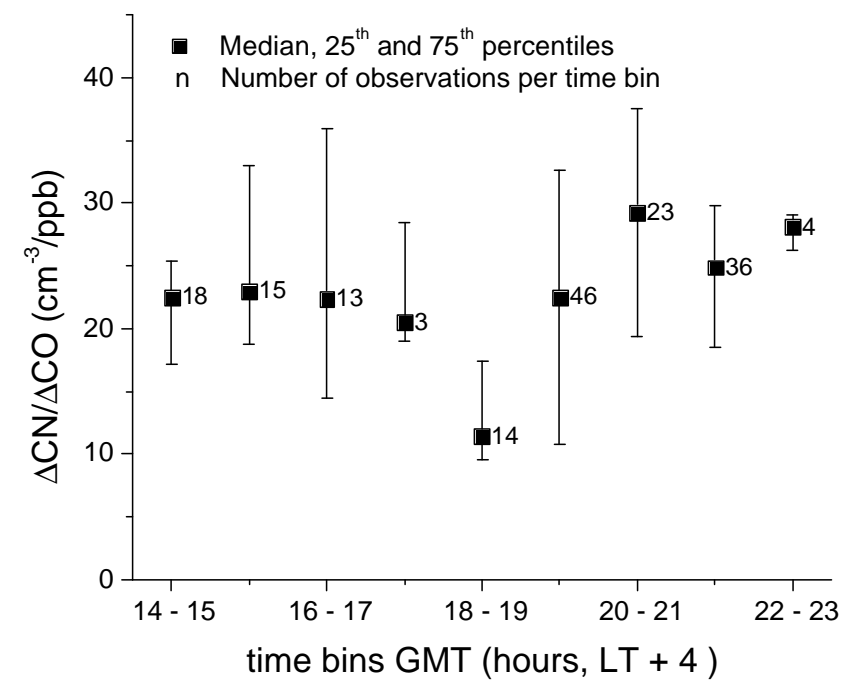

Fig. 3. Diurnal variation of $\mathrm{CN}$-to-CO emission ratios (in $\mathrm{cm}^{-3}$ $\mathrm{CN}$ per ppb $\mathrm{CO}$ ) observed from aircraft measurements during the SMOCC 2002 campaign. Given are median values calculated over hourly time bins. The error bars represent the first and third quartiles of the measurements.

the SMOCC campaign, including haze layers encountered within and above the BL. Very good within-plume correlations were found between $\mathrm{CO}$ and $\mathrm{CO}_{2}$, with $75 \%$ of the $r^{2}$ of the linear fits being $>0.70$, for plume transits lasting ca. 1 min on average. The BL height was determined for each flight primarily from temperature profiles, and confirmed by profiles of potential temperature, specific humidity, and insitu observations of cloud base from the aircraft. Over the Amazon Basin, the height of the fully developed BL in the afternoon lies between ca. 1350 and $1900 \mathrm{~m}$ a.s.l. for most of the time (Fig. 5). Given that the areas over which we flew had surface elevations ranging ca. 100-600 m a.s.1., our values agree well with what was found in previous studies of the BL height in the Amazon Basin (e.g., Nobre et al., 1996; Fisch et al., 2004).

Overall, $\mathrm{ER}_{\mathrm{CO} / \mathrm{CO}_{2}}$ showed a large variability between plumes, with values ranging 1.9-13.4\% and centered on a median value of $6.1 \%$ (first; third quartile: 4.7 ; 7.8), comparable to the range observed by Ward et al. (1991) from three aircraft measurements of Amazonian deforestation fires (Table 1). Our values correspond to a quite efficient - i.e., mostly flaming - combustion, close to what is usually found for savanna plumes (e.g., Hobbs et al., 2003). Few instances of emission ratios indicating smoldering (values larger than ca. $9.0 \%$ ) were detected from the aircraft, which is probably due to the fact that smoldering fires are not as hot and therefore not as convective as flaming fires, and also because smoldering mostly occurs in the evening, when the fires start dying out and convection has ceased. As a matter of fact, most of the smoldering detected was confined within the BL (Fig. 4). It is interesting to note that we found no statistically

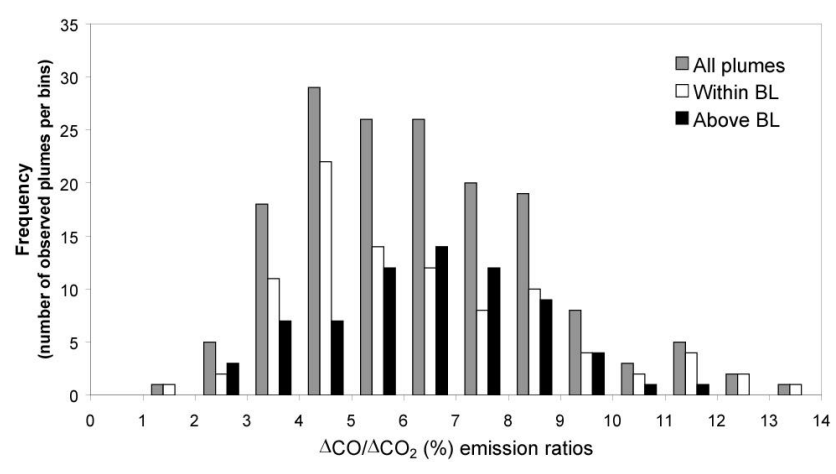

Fig. 4. Frequency distribution of the $\mathrm{CO}-$ to- $-\mathrm{CO}_{2}$ emission ratios (in \%) for all plumes with a $\mathrm{CO}$ enhancement larger than $100 \mathrm{pb}$ that were observed after 17:00 UT during the SMOCC 2002 campaign (gray bars). Also given are the same data segregated into those plumes observed within (white bars) and above (black bars) the boundary layer (BL).

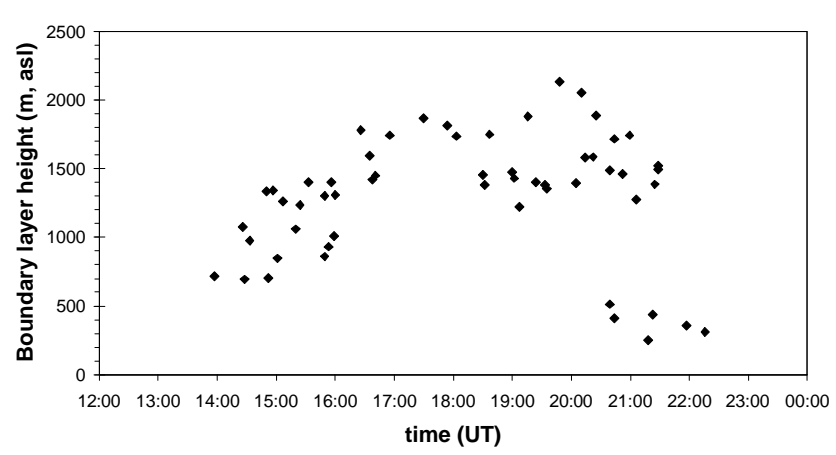

Fig. 5. Observations of boundary layer heights (in meters above sea level) over the Amazon Basin obtained by aircraft measurements of temperature profiles as a function of the time of the day (hours).

significant differences between plumes above and within the BL, even after transforming the data for normality and/or removing the smoldering values responsible for the skewness of the distributions. This confirms that 1) we had little bias due to dilution as described by Mauzerall et al. (1998), and 2) these long-lived gases are efficiently transported by convection from the BL to the FT, where they can undergo long range transport (Andreae et al., 2001).

We computed combustion efficiency (CE), defined as the molar fraction of excess carbon $(\Delta \mathrm{C})$ emitted as $\mathrm{CO}_{2}$ from a fire to the total excess carbon emitted, and emission factors (EF) for $\mathrm{CO}$ according to the definitions of Le Canut et al. (1996) and Andreae and Merlet (2001), respectively:

$$
\begin{aligned}
& \mathrm{CE}=\frac{\Delta \mathrm{C}_{\mathrm{CO}_{2}}}{\Delta \mathrm{C}_{\mathrm{CO}_{2}}+\Delta \mathrm{C}_{\mathrm{CO}}+\Delta \mathrm{C}_{\mathrm{OC}}+\Delta \mathrm{C}_{\mathrm{PC}}} \approx \frac{1}{1+1.2 \times \frac{\Delta \mathrm{CO}}{\Delta \mathrm{CO}_{2}}} \\
& \mathrm{EF}_{X}=\mathrm{ER}_{\mathrm{X} / \mathrm{Y}} \times \frac{\mathrm{MW}_{\mathrm{X}}}{\mathrm{MW}_{\mathrm{Y}}} \times \mathrm{EF}_{\mathrm{Y}}
\end{aligned}
$$

where the subscripts $\mathrm{OC}$ and PC indicate total carbon in organic gases and particulate compounds, respectively, and 
Table 1. $\mathrm{ER}_{\mathrm{CO} / \mathrm{CO}_{2}}$ and $\mathrm{EF}_{\mathrm{CO}}$ for tropical deforestation fires. When not given, $\mathrm{ER}_{\mathrm{CO} / \mathrm{CO}_{2}}$ was obtained from $\mathrm{EF} \mathrm{CO}$ (or reverse) using equation 3 and the published value of $\mathrm{EF}_{\mathrm{CO}_{2}}$, which was otherwise assumed to be $1580 \mathrm{~g} \mathrm{~kg}^{-1} \mathrm{dm}$ (values identified by a star). When given in terms of $\mathrm{g} \mathrm{kg}^{-1} \mathrm{C}$, values were converted to dry matter assuming a carbon content of the fuel of $45 \%$ (values identified by a cross), or using the published value.

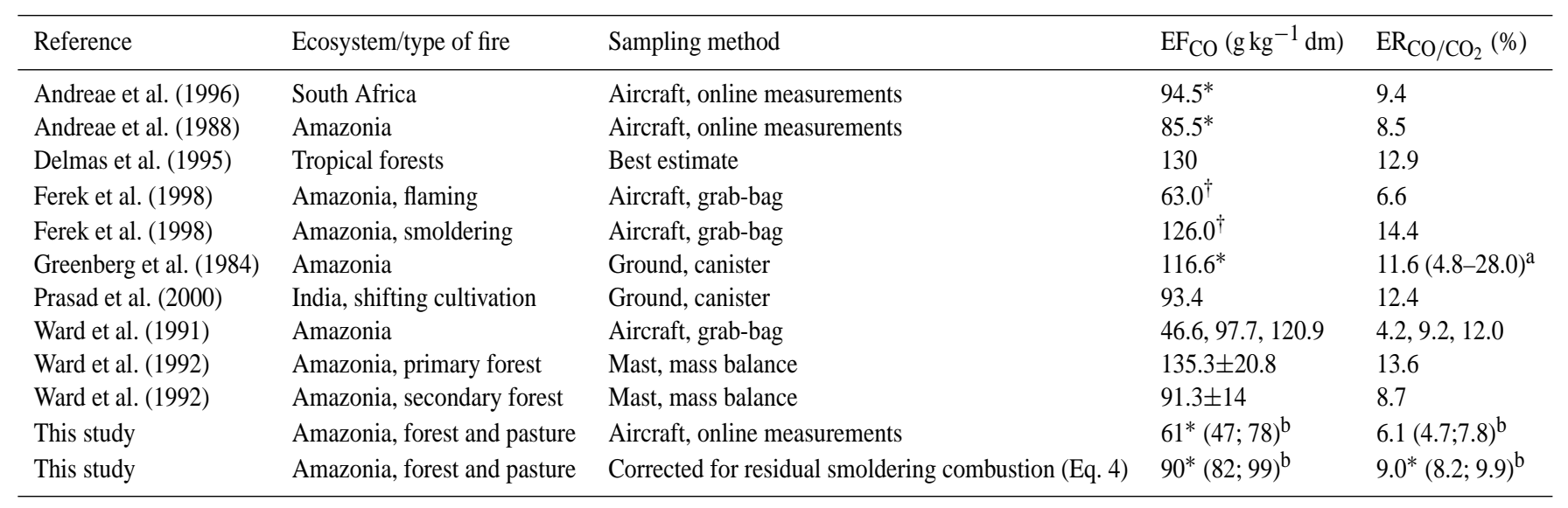

a Range of 1 standard deviation around the mean of log-normal distribution.

b Median (First; Third quartile).

$\mathrm{MW}_{\mathrm{X}}$ and $\mathrm{MW}_{\mathrm{Y}}$ the molecular weights of species $\mathrm{X}$ and $\mathrm{Y} . \mathrm{EF}_{\mathrm{Y}}$, the emission factor of the reference species $\mathrm{Y}$, here $\mathrm{EF}_{\mathrm{CO}_{2}}$, was taken to be $1580 \mathrm{~g} \mathrm{~kg}^{-1} \mathrm{dm}$ (dm is the dry matter of fuel) (Andreae and Merlet, 2001). We found CE values centered on a median value of 0.93 (0.91; 0.95), comparable to what is usually found for the efficiently burning savanna fires (e.g., Le Canut et al., 1996). Our $\mathrm{EF}_{\mathrm{CO}}$ showed a median value of $61(47 ; 78) \mathrm{g} \mathrm{kg}^{-1} \mathrm{dm}$. They are in the lower end of the values usually found in the literature for tropical forest fires, considerably lower than the average value of $104 \pm 20$ given by Andreae and Merlet (2001) for tropical forest, and, again, closer to the global average value of $65 \pm 20$ given by these authors for savanna fires.

The main reason for our low EF is probably that a significant fraction of the fire emissions is not sampled by the aircraft. A large part of the smoldering fraction during daytime is entrained and sampled by the aircraft, but does not make a large contribution. Visual observation shows, however, that even during daytime, smoke from the less active parts of the fires is injected at low altitude, and does not form part of the plume sampled by the aircraft. The nighttime smoldering fraction is missed completely, as is the fraction released from lingering long-term burning, which can last for several days for deforestation fires. This residual smoldering combustion (RSC) has been estimated to contribute up to $38-44 \%$ of the total biomass consumed for pasture maintenance burns (Kauffman et al., 1998), but could be as large as $50 \%$ for deforestation fires as observed for temperate and boreal forests (Bertschi et al., 2003). We have estimated the fire integrated $\mathrm{EF}\left(\mathrm{EF}_{i, \text { tot }}\right)$ for the species $i$, here $\mathrm{CO}$, using our estimate of
$\mathrm{EF}_{\mathrm{CO}}$ and the definition of Bertschi et al. (2003):

$\mathrm{EF}_{i, \text { tot }}=(f) \times \mathrm{EF}_{i, \mathrm{RSC}}+(1-f) \times \mathrm{EF}_{i, \text { conv }}$

where $\mathrm{EF}_{i, \mathrm{RSC}}$ and $\mathrm{EF}_{i, \text { conv }}$ are the $\mathrm{EF}$ of species $i$ in RSC and in the lofted emissions as measured from aircraft sampling, respectively. $f$, the fraction of fuel consumed by RSC, was taken to be $44 \%$ which is the upper limit given by Kauffman et al. (1998) since we measured a mixture of deforestation and pasture maintenance fires. Assuming an $\mathrm{EF}_{\mathrm{CO}, \mathrm{RSC}}$ of $126 \mathrm{~g} \mathrm{~kg}^{-1} \mathrm{dm}$ (Ferek et al., 1998), we obtained a $\mathrm{EF}_{\mathrm{CO} \text {,tot }}$ median value of $90 \mathrm{~g} \mathrm{~kg}^{-1} \mathrm{dm}$, probably more representative of the total emissions of $\mathrm{CO}$ for deforestation/pasture maintenance fires.

Table 1 gives an overview of the $\mathrm{ER}_{\mathrm{CO} / \mathrm{CO}_{2}}$ and $\mathrm{EF}_{\mathrm{CO}}$ measured for tropical forests so far. It can be seen that overall the $\mathrm{EF}_{\mathrm{CO}}$ values obtained from aircraft measurements, ranging $41-126 \mathrm{~g} \mathrm{~kg}^{-1} \mathrm{dm}$ (the latter being a specific smoldering sample), are lower than those obtained at ground level, where the averages range $91-135 \mathrm{~g} \mathrm{~kg}^{-1} \mathrm{dm}$ and maxima go as high as 152 (Ward et al., 1992) and 280 (Greenberg et al., 1984). It is obvious that aircraft measurements of EF are biased toward hot, convective (flaming) combustion, while groundbased measurements may be dominated by smoldering emissions. Hence, the two types of measurements are complementary and should both be used in order to retrieve realistic EF, especially for deforestation fires. This could be done with the help of the correction provided by Eq. (4) (Bertschi et al., 2003) which requires better estimates of RSC fractions for the various ecosystems. When deducing biomass burning from satellite $\mathrm{CO}$ data, care should be taken to avoid the bias resulting from different emission factors applicable to 
different injection heights. Our values are representative of the fraction of the emissions that are uplifted to the FT in the region near the fire. However, when the total amount of emission is needed, as in large-scale models, values corrected for RSC should be used.

\section{2 $\mathrm{CN}$-to-CO emission ratios $\left(\Delta \mathrm{CN} / \Delta \mathrm{CO}\right.$ or $\left.\mathrm{ER}_{\mathrm{CN} / \mathrm{CO}}\right)$ and $\mathrm{CN}$ emission factors}

Figure 6 presents the frequency distribution of all $\mathrm{ER}_{\mathrm{CN} / \mathrm{CO}}$ values obtained during the campaign (number of observations: $n=172$ ), separated by their sampling location within or above the BL. The linear regression of $\mathrm{CN}$-to-CO yielded statistically significant correlation coefficients, with $75 \%$ of the $r^{2}$ being larger than 0.84 . This emphasizes that $\mathrm{CO}$ is a useful tracer for computing $\mathrm{CN}$ number concentrations from biomass burning, which is probably due to the fact that both $\mathrm{CO}$ and particles are primarily released during the nonflaming phases (pyrolysis and smoldering) of the combustion. Overall, $E R_{\mathrm{CN} / \mathrm{CO}}$ ranged 3-76 particles per $\mathrm{cm}^{3}$ and per ppb of $\mathrm{CO}$, with a median value of $23 \mathrm{~cm}^{-3} \mathrm{ppb}^{-1}$ (14; 32 ). Most values fall into a remarkably narrow range, given the large number of plumes we observed and the large area we covered over the Amazon forest, stressing the fact that the number of particles per unit $\mathrm{CO}$ emitted from deforestation fires in the Amazon is a relatively constant parameter. Compared to what can be found in the literature, our values are in the range of those published for fresh savanna fires in Africa (16-36 $\mathrm{cm}^{-3} \mathrm{ppb}^{-1}$, e.g., Le Canut et al., 1996; Hobbs et al., 2003) and in the Amazon (10-30 $\mathrm{cm}^{-3} \mathrm{ppb}^{-1}$, Andreae et al., 2001), further stressing the idea that the number of particles emitted per unit $\mathrm{CO}$ from wild fires is a stable parameter. No previous data are available for Amazonian deforestation fires.

When fresh smoke plumes from hot fires are lifted up high enough to reach the cloud condensation level, a so-called pyro-cloud (Andreae et al., 2004) is formed. Since the formation of precipitation is often suppressed in these clouds due to the extremely high $\mathrm{CN}$ concentrations they contain (Andreae et al., 2004), particles are released in the CDL and FT and could be measured as detrained smoke plumes by the aircraft. In fact, we also observed plumes directly smoking out of those pyro-clouds. Only little difference can be observed when comparing the distribution of the data above $(n=91)$ and within $(n=81)$ the BL (Fig. 6). However, this difference was found to be statistically significant by a nonparametric test ( $p=0.01$, medians are 20 and 25 for above and within the BL, respectively), and confirmed by t-test after applying a square-root transformation to the data. Since precipitation is expected to form in polluted clouds only at altitudes considerably higher than we could sample during SMOCC (Andreae et al., 2004), it is likely that the plumes we investigated resulted mostly from detrainment from nonprecipitating clouds. This suggests that the $20 \%$ particle loss is mainly attributable to coagulation occurring in the clouds

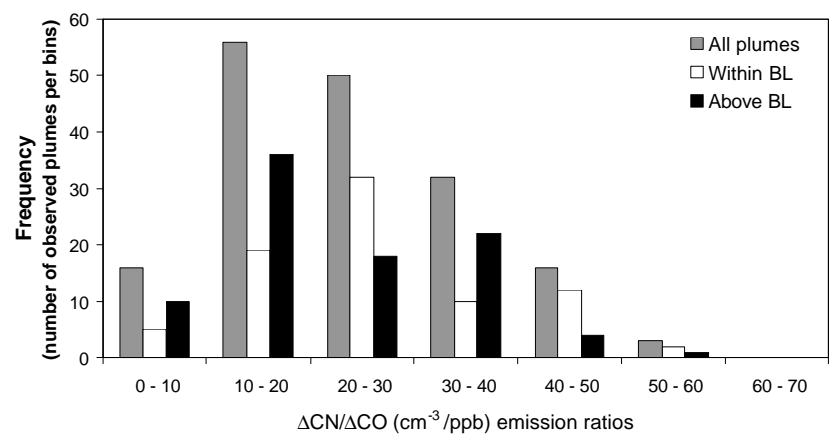

Fig. 6. Frequency distribution of the $\mathrm{CN}$-to- $\mathrm{CO}$ emission ratios (in particles per $\mathrm{cm}^{3}$ and per ppb $\mathrm{CO}$ ) for all plumes with a $\mathrm{CO}$ enhancement larger than $100 \mathrm{ppb}$ that were observed during the SMOCC 2002 campaign (gray bars). Also given are the same data segregated into those plumes observed within (white bars) and above (black bars) the boundary layer (BL).

(see also Sect. 3.3 below). Thus, since a considerable fraction of aerosol particles is released from these non-precipitating clouds, this mode of transport from the BL to the CDL and FT can be considered to be rather efficient in terms of aerosol numbers.

Figure 3 presents the diurnal course of the $\mathrm{ER}_{\mathrm{CN} / \mathrm{CO}}$ data. From this figure, it can be observed that most data are in the range 20-30 through the day, except for a reduced value (median of $11(10 ; 17))$ at 18-19 UT $(14-15$ LT), due to mostly cloud-processed plumes sampled at that time. These values are similar to the $\mathrm{ER}_{\mathrm{CN} / \mathrm{CO}}=15(10 ; 21)$ observed at the FNS ground observation station at night, when concentrated plumes were advected from nearby fires to the site. These plumes observed at the FNS at night are supposedly mostly smoldering plumes that get trapped within the shallow nocturnal boundary layer, but no $\mathrm{CO}_{2}$ data from ground level were available to confirm this hypothesis. Similar observations were obtained from a laboratory experiment on the combustion of wood, grass, and peat using the same setup as described by Lobert et al. (1991). $\mathrm{ER}_{\mathrm{CN} / \mathrm{CO} \text { was observed }}$ to decrease from 25 to 15 together with increasing $\mathrm{ER}_{\mathrm{CO} / \mathrm{CO}_{2}}$ values from 4 to $10 \%$, and remained constant at a value of ca. 12 (ranging ca. 8-14) for $\mathrm{ER}_{\mathrm{CO} / \mathrm{CO}_{2}}>10 \%$ (O. Schmid, personal communication, 2004). A value of ca. 22 was found for $\mathrm{ER}_{\mathrm{CN} / \mathrm{CO}}$ at $\mathrm{ER}_{\mathrm{CO} / \mathrm{CO}_{2}=6 \% \text {, corresponding to our observed }}$ maximum in the frequency distribution. A dependence of $\mathrm{ER}_{\mathrm{CN} / \mathrm{CO}}$ on $\mathrm{ER}_{\mathrm{CO} / \mathrm{CO}_{2}}$ was not clearly observable in our data. However, the good agreement between our data and these laboratory measurements tend to confirm the surprising steadiness of the $\mathrm{ER}_{\mathrm{CN} / \mathrm{CO}}$ for various types of fuel at a given combustion efficiency. The slightly lower $\mathrm{ER}_{\mathrm{CN} / \mathrm{CO}}$ value obtained from the laboratory experiment at equivalent $\mathrm{ER} \mathrm{CO} / \mathrm{CO}_{2}$ together with the laboratory observation that $\mathrm{ER}_{\mathrm{CN} / \mathrm{CO}}$ decreases with smoldering could be interpreted as an indication that the aircraft measurements might slightly overestimate $\mathrm{ER}_{\mathrm{CN} / \mathrm{CO}}$. 


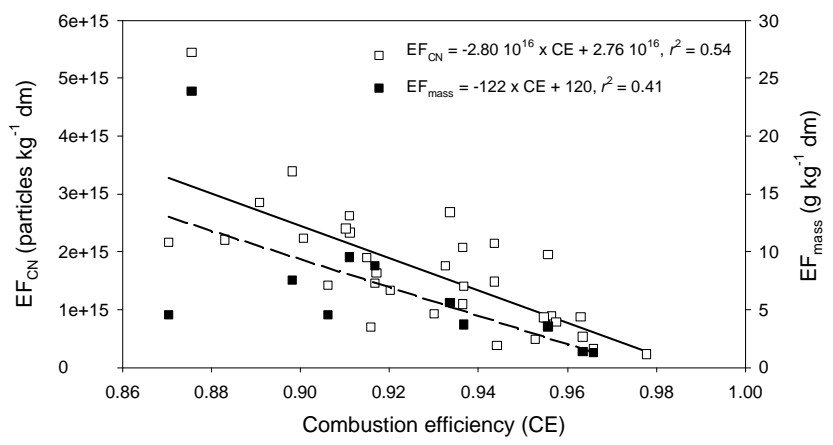

Fig. 7. Scatter plots and linear regressions of $\mathrm{EF}_{\mathrm{CN}}$ (open squares, black line) and $\mathrm{EF}_{\text {mass }}$ (black squares, dashed line) on $\mathrm{CE}$.

Emission factors of $\mathrm{CN}\left(\mathrm{EF}_{\mathrm{CN}}\right)$, which were obtained using equation 3 , ranged $2.3 \times 10^{14}-5.4 \times 10^{15}$ particles emitted per $\mathrm{kg}$ dry matter burned $\left(\mathrm{kg}^{-1} \mathrm{dm}\right)$, and were centered on $\mathrm{EF}_{\mathrm{CN}}=1.5 \times 10^{15} \mathrm{~kg}^{-1}(\mathrm{dm})\left(0.87 \times 10^{15} ; 2.2 \times 10^{15}\right)$, about half the estimate for total particle number emissions published by Andreae and Merlet (2001), based on laboratory studies. O. Schmid and co-workers observed $\mathrm{EF}_{\mathrm{CN}}$ ranging ca. $0.5-1.5 \times 10^{15} \mathrm{~kg}^{-1}(\mathrm{dm})$ from the first phase (no RSC) of grass and wood combustion (personal communication). As observed already for Amazonian and African savanna fires, the emission of particles from fresh fires showed a dependence on the combustion efficiency of the fire (Ward et al., 1992; Le Canut et al., 1996; Ward et al., 1996). For the times when $\mathrm{CO}, \mathrm{CO}_{2}$, and $\mathrm{CN}$ data were available simultaneously for fresh plumes measured within the BL $(n=34)$, we obtained a linear correlation of $\mathrm{EF}_{\mathrm{CN}}$ on $\mathrm{CE}$ (Fig. 7). This confirms that, for Amazonian deforestation and pasture burning also, more particles are emitted at lower CE, i.e. toward the smoldering state. The $r^{2}$ of the linear regression was found to worsen when using the data measured above the BL, probably because of a non-linear loss of particles during vertical and cloud transport and aging. The dependence of $\mathrm{EF}_{\mathrm{CN}}$ on $\mathrm{CE}$ indicates that when correcting it for $\mathrm{RSC}, \mathrm{EF}_{\mathrm{CN}}$ would tend to increase, as opposed to what Bertschi et al. (2003) suggested for particulate mass emissions from boreal forest fires. Taking our average $\mathrm{CE}$ value of 0.93 and a typical $\mathrm{CE}$ value of 0.85 for smoldering (RSC) conditions (Ferek et al., 1998), our regression of $\mathrm{EF}_{\mathrm{CN}}$ on $\mathrm{CE}$ suggests that $\mathrm{EF}_{\mathrm{CN}}$ increases by a factor of ca. 2.2 when accounting for the RSC fraction. Applying the above equation 4 and related assumptions yielded $\mathrm{EF}_{\mathrm{CN}}$ of $2.5 \times 10^{15}\left(2.2 \times 10^{15} ; 2.9 \times 10^{15}\right)$, resulting in a much better agreement with the laboratory results reported by Andreae and Merlet (2001). This points out the urgency of studying the effects of RSC on biomass burning emissions, especially for particles, for which there is no other estimate to date.

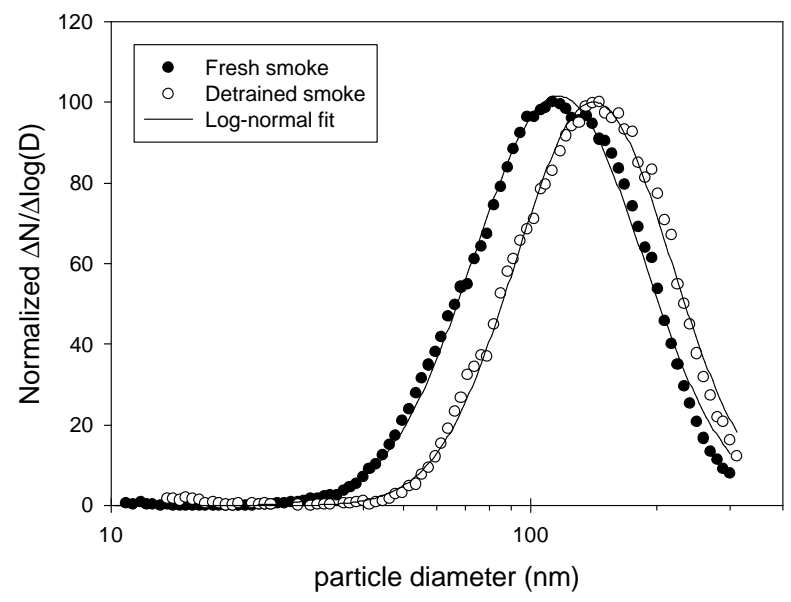

Fig. 8. Aerosol particle number size distribution of a fresh smoke plume (black dots) and a detrained smoke plume (open circles) from the "Pista de Cabeça" deforestation fire (PCF) observed on 1 October 2002. The black curves represent the log-normal fits to the distributions.

\subsection{Emissions of smoke aerosol particles and cloud pro- cessing}

In a further step, we have derived emission ratios of particle surface, volume, and mass to $\mathrm{CO}\left(\mathrm{ER}_{\text {surf } / \mathrm{CO}}, \mathrm{ER}_{\mathrm{vol} / \mathrm{CO}}\right.$, and $\mathrm{ER}_{\text {mass/CO}}$, respectively), as well as particle scattering-to-CO ( $\Delta$ scattering/ $\Delta \mathrm{CO}$ or $\mathrm{ER}_{\text {scatt } / \mathrm{CO}}$ ), which was computed in the same manner as described above for the other parameters. Aerosol surface, volume, and mass were obtained from the size distributions of the plumes measured with the help of a SMPS. Since a size distribution measurement cycle took 2 min, it was not possible to derive ER of these quantities to $\mathrm{CO}$ from regression analysis. Therefore, in a first step, the measured number size distribution of each plume of interest was fitted with a log-normal curve in order to compare the geometric mean diameters and standard deviations of the distributions (see, e.g., Fig. 8). The curve fitting was only applied to accumulation mode particles (Fig. 8) because coarse particles, which contribute little to the aerosol number, were not measured, and the accumulation mode was the only mode observed within the measurement range. Then, when $\mathrm{ER}_{\mathrm{CN} / \mathrm{CO}}$ data were available, the fitted size distribution was integrated for surface and volume over the observed $\mathrm{ER}_{\mathrm{CN} / \mathrm{CO}}$ for that plume.

A total of 69 plumes sampled within the BL and 50 sampled above could be successfully fitted with a log-normal curve, with $75 \%$ of the $r^{2}>0.98$. We obtained average geometric mean diameters $\left(D_{50}\right)$ of $110 \pm 15 \mathrm{~nm}$ for those plumes sampled within the BL and $139 \pm 17 \mathrm{~nm}$ for those above. Associated standard deviations $(\ln \sigma)$ were $0.50 \pm 0.06$ and $0.45 \pm 0.05$, respectively. These values are in the range of what was typically found for Amazonian deforestation fires (e.g., Reid and Hobbs, 1998; Reid et al., 1998; Vestin et 
Table 2. Summary of the results (median (first; third quartile), $n$ ) of emission ratios of aerosol particles to $\mathrm{CO}$ and of $\mathrm{CO}_{-}$to- $\mathrm{CO}{ }_{2}$ for the plumes observed within and above the boundary layer.

\begin{tabular}{llllll}
\hline & $\mathrm{ER}_{\mathrm{CO} / \mathrm{CO}_{2}}(\%)$ & $\begin{array}{l}\mathrm{ER}_{\mathrm{CN} / \mathrm{CO}} \\
\left(\# \mathrm{~cm}^{-3} \mathrm{ppb}^{-1}\right)\end{array}$ & $\begin{array}{l}\mathrm{ER}_{\mathrm{surf} / \mathrm{CO}} \\
\left(\mu \mathrm{m}^{2} \mathrm{~cm}^{-3} \mathrm{ppb}^{-1}\right)\end{array}$ & $\begin{array}{l}1000 \times \mathrm{ER}_{\mathrm{vol} / \mathrm{CO}} \\
\left(\mu \mathrm{m}^{3} \mathrm{~cm}^{-3} \mathrm{ppb}^{-1}\right)\end{array}$ & $\begin{array}{l}\mathrm{ER}_{\mathrm{scat} / \mathrm{CO}} \\
\left(\mathrm{Mm}^{-1} \mathrm{ppb}^{-1}\right)\end{array}$ \\
\hline All plumes & $6.1(4.7 ; 7.8), 163$ & $23(14 ; 32), 172$ & $2.1(1.5 ; 2.6), 68$ & $77.3(55.7 ; 103.7), 68$ & $0.82(0.66 ; 1.15), 149$ \\
Plumes in BL & $5.7(4.5 ; 7.8), 93$ & $25(19 ; 36), 91$ & $1.6(1.3 ; 2.2), 29$ & $58.4(43.8 ; 71.2), 29$ & $0.73(0.43 ; 0.86), 80$ \\
Detrained plumes & $6.4(5.0 ; 7.7), 70$ & $20(12 ; 31), 81$ & $2.5(1.7 ; 2.9), 39$ & $91.6(71.4 ; 114.4), 39$ & $1.13(0.81 ; 1.32), 69$ \\
\hline
\end{tabular}

al., 2005 ${ }^{1}$ ). The differences in $D_{50}$ and $\ln \sigma$ between BL plumes and detrained ones were statistically significant (ttest, $p<0.001$ ). Since we found no significant difference in relative humidity between the plumes observed within the BL and those above (both averaged ca. 60\%), we conclude that, overall, the relative humidity did not influence the size of the particles. Moreover, hysteresis experiments at the FNS ground site have shown that when bringing these particles to deliquescence and drying them again to their original $\mathrm{RH}$ condition of 50-60\% (a situation comparable to ours for detrained particles), no hysteresis was observed (i.e., the size distribution of the deliquesced-and-dried particles was identical to that of the original ones at the same RH) (Vestin et al., 2005) ${ }^{1}$. There is no reason for our particles to behave differently, so that we can exclude that water uptake and a subsequent hysteresis effect contributed significantly to the growth we observed for the detrained particles.

Table 2 provides a summary of the results of emission ratios of aerosol particle number, surface, and volume, relative to $\mathrm{CO}$. In both cases, ER of detrained particles increased significantly compared to the aerosols in the BL (t-tests, $p<0.01$ and 0.001 for surface and volume, respectively). Particle coagulation contributes to decreasing the number of particles (ER $\mathrm{CN}_{\mathrm{CO}}$ of ca. 20 in the cloud processed smoke versus ca. 25 in BL), resulting in fewer, larger particles. However, coagulation does not modify the total volume of the particles, and the observed increase in normalized particulate surface and volume must be attributed to secondary growth. This issue will be discussed in detail in a forthcoming publication.

The $\mathrm{ER}_{\mathrm{vol} / \mathrm{CO}}$ values for $\mathrm{BL}$ plumes translated into aerosol mass emission factors $\left(\mathrm{EF}_{\text {mass }}\right)$ of $4.5(3.6 ; 8.2) \mathrm{g} \mathrm{kg}^{-1} \mathrm{dm}$ $(n=11)$ when using a typical particle density for Amazonian smoke particles of $1.35 \mathrm{~g} \mathrm{~cm}^{-3}$ (Reid and Hobbs, 1998; Guyon et al., 2003). Our $\mathrm{EF}_{\text {mass }}$ values for accumulation mode particles are at the lower end of what was found previously for Amazonian deforestation PM2.5 and PM4 emission factors, which ranged $5.3-15.6 \mathrm{~g} \mathrm{~kg}^{-1} \mathrm{dm}$ for flaming and smoldering fires, respectively (Ward et al., 1991; Ward et al., 1992; Ferek et al., 1998). The difference may be at least in part attributable to particles larger than those represented by our lognormal size mode fits. However, it is still not clear

\footnotetext{
${ }^{1}$ Vestin, A., Rissler, J., Swietlicki, E., Frank, G. P., and Andreae, M. O.: Cloud nucleating properties of the Amazonian dry season biomass burning aerosol - Measurements and modeling, in preparation, 2005.
}

to which extent the missed RSC fraction might have affected our data. Using equation 4, making the same assumptions as above, and using the equation from the linear regression of $\mathrm{EF}_{\text {mass }}$ on $\mathrm{CE}$ (Fig. 7) yielded an $\mathrm{EF}_{\text {mass }}$ of $9.2(8.7 ; 11.3)$ $\mathrm{g} \mathrm{kg}^{-1} \mathrm{dm}$. We note here that eliminating the two data points at low $\mathrm{CE}$ would have increased the $r^{2}$ of the regression to 0.7 , without changing the regression slope significantly. Table 3 provides a summary of the aerosol-related EFs obtained in this study, both when using the data from the convective plumes as sampled from the aircraft and when correcting for RSC, to obtain values representative of the total emissions.

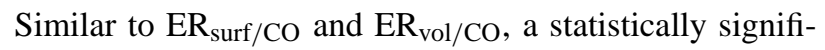
cant difference $(p<0.001)$ was observed between the amount of scattering per $\mathrm{CO}\left(\mathrm{ER}_{\mathrm{scatt} / \mathrm{CO}}\right)$ observed in plumes encountered within and those above the BL, the latter being overall larger (data summarized in Table 2). Moreover, the values for the back-scattering ratio at the wavelength $\lambda$ of $700 \mathrm{~nm}\left(b_{(700)}\right)$, and the Ångström coefficients at $\lambda=450$ and $550 \mathrm{~nm}\left(\stackrel{\circ}{a}_{(450 / 550)}\right)$, and at $\lambda=450$ and $700 \mathrm{~nm}$ $\left(\stackrel{\circ}{(}_{(450 / 700)}\right)$ averaged over each of the corresponding plumes were all three statistically significantly larger for the plumes measured within the BL compared to the detrained ones. This confirms that the cloud-processed aerosols are significantly larger, and, therefore, scatter more efficiently than the freshly produced aerosols, overbalancing their lower number concentration per amount of $\mathrm{CO}$ and resulting in larger

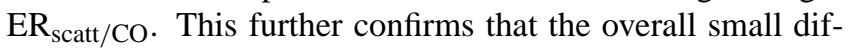
ference between the $\mathrm{ER}_{\mathrm{CN} / \mathrm{CO}}$ observed for fresh plumes (ca. 25) and processed aerosols (ca. 20) is not due to a new aerosol formation occurring in the detraining region of the cloud that would compensate for a larger aerosol loss during transport and cloud processing, but rather that this means of transport is very efficient at releasing biomass burning aerosols into the CDL and FT. Moreover, the released particles, having grown through cloud processing, are not only much more efficient at scattering incoming radiation, they are also much more efficient cloud condensation nuclei (CCN); for more details, see Andreae et al. (2004) and Frank et al. $(2005)^{2}$.

\footnotetext{
${ }^{2}$ Frank, G. P., Rissler, J., Roberts, G., Guyon, P., Swietlicki, E., Vestin, A., Zhou., J., Mayol-Bracero, O. L., González, S., Costa, A., Rizzo., L., Chand, D., Schmid, O., Artaxo, P., and Andreae, M. O.: Cloud condensation nuclei concentrations and efficiencies in the Amazon Basin, Atmos. Chem. Phys., in preparation, 2005.
} 
Table 3. Summary of the results (median (first; third quartile), $n$ ) of emission factors of accumulation mode aerosol particles to CO for the plumes observed within and above the boundary layer.

\begin{tabular}{llll}
\hline & $\begin{array}{l}\mathrm{EF}_{\mathrm{CN}} \\
\left(10^{15} \mathrm{~kg}^{-1} \mathrm{dm}\right)\end{array}$ & $\begin{array}{l}\mathrm{EF}_{\mathrm{vol}} \\
\left(\mathrm{cm}^{3} \mathrm{~kg}^{-1} \mathrm{dm}\right)\end{array}$ & $\begin{array}{l}\mathrm{EF}_{\text {mass }}{ }^{\mathrm{a}} \\
\left(\mathrm{g} \mathrm{kg}^{-1} \mathrm{dm}\right)\end{array}$ \\
\hline Plumes in FT (detrained) & $1.3(0.67 ; 2.2), 53$ & $6.4(4.4 ; 8.4), 34$ & $8.6(5.9 ; 11.3), 34$ \\
Plumes in BL & $1.5(0.87 ; 2.2), 34$ & $3.3(2.7 ; 6.1), 11$ & $4.5(3.6 ; 8.2), 11$ \\
Plumes in BL, corrected for RSC & $2.5(2.2 ; 2.9), 34$ & $6.8(6.4 ; 8.4), 11$ & $9.2(8.7 ; 11.3), 11$ \\
\hline
\end{tabular}

${ }^{\mathrm{a}}$ Using a density of $1.35 \mathrm{~g} \mathrm{~cm}^{-3}$.

\subsection{Case Studies}

\subsubsection{The "Pista de Cabeça" deforestation fire}

Most of the plumes studied in this work were from fires encountered randomly while the plane was flying. The Pista de Cabeça fire, in contrast, was a deforestation fire that was conducted in collaboration with other LBA research activities, and therefore we had prior knowledge of place and time as well as detailed information on the vegetation and burning conditions. The 230 ha square plot contained forest material which had been cut between the end of March and the beginning of July and left for curing. It was situated at $10.45^{\circ} \mathrm{S}$, $56.50^{\circ} \mathrm{W}$, and ca. $300 \mathrm{~m}$ a.s.l. in a Fazenda close to the town of Alta Floresta, Mato Grosso, Brazil. By law, the fire could only be started toward the end of the dry season, on 1 October 2002, and the biomass was quite moist at the time the experiment started, due to the unexpected increase in rain frequency. The plot was ignited all around the borders of the slashed areas at about 13:30 LT, and by 20:00 LT all flames were gone due to excessive fuel moisture, while only ca. $10 \%$ of the plot had burned, starting at the borders. However, at ca. 15:00 LT, when the aircraft reached the area, the fire was observed to be in a mixed flaming and smoldering phase and was intensive enough that the smoke plume was evolving into a large pyro-cloud. We performed three passes (A, B, and C) through the main smoke plume at $1230-1300 \mathrm{~m}$ a.s.l. followed by a penetration of the detrained plume (D) smoking out of the pyro-cloud at $2250 \mathrm{~m}$ a.s.l. A summary of the results is given in Table 4. Unfortunately the CPC was not available during this experiment due to overheating of the instrument. The $\mathrm{ER}_{\mathrm{CO} / \mathrm{CO}_{2}}$ obtained from the three passes through the fresh smoke ranged from values typical of the middle of the range obtained from all BL plumes (Fig. 4) to large values, corresponding to mid-range (mostly flaming) to low combustion efficiency (smoldering). This indicates that a specific Amazonian deforestation fire cannot be characterized by a single value of $\mathrm{ER}_{\mathrm{CO} / \mathrm{CO}_{2}}$ or $\mathrm{CE}$ because these fires are very inhomogeneous. They can simultaneously be in a flaming and smoldering phase, with rapidly changing combustion conditions depending on numerous parameters such as wind, fuel density, size and moisture, etc. This is in con- trast to, e.g., savanna fires, which are usually running fires over more or less homogeneous vegetation. Therefore, it is necessary to collect data from many forest fires in order to improve statistics, and better understand their overall emissions.

The behavior of the aerosols for this particular fire confirmed the general trend observed above. While $\mathrm{ER}_{\mathrm{CO} / \mathrm{CO}_{2}}$ of the pyrocloud-detrained smoke remained unchanged compared to the smoke below cloud-base, the aerosols grew in size from a number modal diameter of 116 to one of $142 \mathrm{~nm}$ (Fig. 8) and light scattering increased (Table 4). In the present case, no significant difference was found in the backscatter ratios and Ångström coefficients. Given the relatively small increase in the corresponding volume modal diameter (from 207 to $247 \mathrm{~nm}$ ) only a small change in å would be expected from Mie theory (ca. 0.1 to 0.2 ), within the error of the determination.

\subsubsection{The Santa Lucia fire}

The Santa Lucia fire was a large fire of opportunity, which we studied intensively on 30 September 2002. The fire was a deforestation fire, situated south of the town of Vilhena, Rondônia, ca. $14.12^{\circ} \mathrm{S}, 60.17^{\circ} \mathrm{W}$. The fire was observed to be in a relatively late stage, with little flames. A pyrocloud had developed at the top of the plume. We passed five times through the main fresh plume as well as secondary plumes (from which we obtained the $\mathrm{CN}$ data, because the CPC was saturating in the main plume) at altitudes of 850-1050 ma.s.l. Again, we observed a large sampleto-sample variation in the data. In the fresh plume, we obtained $\mathrm{ER}_{\mathrm{CO} / \mathrm{CO}_{2}}$ ranging 4.2-12.4\%. Correspondingly,

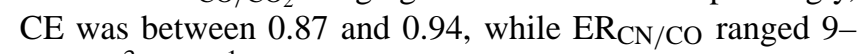
$35 \mathrm{~cm}^{-3} \mathrm{ppm}^{-1}$ (Table 5). These values from this fire cover most of the range of the observed values for all fires measured during this campaign, emphasizing again the difficulty of characterizing Amazonian deforestation fires. This is probably the reason why we were not able to distinguish a significantly different signature between deforestation fires and secondary-growth pasture fires. 
Table 4. Results from the Pista de Cabeca deforestation fire (PCF).

\begin{tabular}{|c|c|c|c|c|c|c|c|c|c|}
\hline $\begin{array}{c}\text { Plume } \\
\#\end{array}$ & $\mathrm{CE}$ & $\begin{array}{c}\mathrm{ER}_{\mathrm{CO} / \mathrm{CO}_{2}}{ }^{\mathrm{a}} \\
(\%)\end{array}$ & $\begin{array}{c}\mathrm{EF}_{\mathrm{CO}} \\
\left(\mathrm{g} \mathrm{kg}^{-1} \mathrm{dm}\right)\end{array}$ & $\begin{array}{l}\mathrm{ER}_{\text {scatt } / \mathrm{CO}}^{\mathrm{a}} \\
\left(\mathrm{Mm}^{-1} \mathrm{ppb}^{-1}\right)\end{array}$ & $b_{(700)} \mathrm{b}$ & $\stackrel{\circ}{a}_{(450 / 550)} \mathrm{b}$ & $\stackrel{\circ}{a}_{(450 / 700)} \mathrm{b}$ & $D_{50}{ }^{\mathrm{c}}$ & $\begin{array}{l}\ln (\sigma)^{\mathrm{c}} \\
(\mathrm{nm})\end{array}$ \\
\hline A & 0.875 & $11.9 \pm 0.4$ & 119.8 & $0.33 \pm 0.01$ & $0.226 \pm 0.032$ & $2.258 \pm 0.128$ & $2.485 \pm 0.135$ & $117.7 \pm 0.4$ & 0.424 \\
\hline B & 0.929 & $6.4 \pm 0.4$ & 63.9 & $0.55 \pm 0.02$ & $0.222 \pm 0.024$ & $2.238 \pm 0.197$ & $2.449 \pm 0.156$ & $114.2 \pm 0.3$ & $0.437 \pm 0.003$ \\
\hline $\mathrm{C}$ & 0.931 & $6.1 \pm 0.5$ & 61.7 & $0.52 \pm 0.03$ & $0.232 \pm 0.032$ & $2.297 \pm 0.193$ & $2.497 \pm 0.185$ & $116.6 \pm 0.4$ & $0.465 \pm 0.004$ \\
\hline D & 0.904 & $8.8 \pm 0.2$ & 88.6 & $0.67 \pm 0.02$ & $0.217 \pm 0.018$ & $2.295 \pm 0.129$ & $2.522 \pm 0.097$ & $141.6 \pm 0.5$ & $0.426 \pm 0.004$ \\
\hline
\end{tabular}

${ }^{\mathrm{a}} \mathrm{ER}_{\mathrm{CO} / \mathrm{CO}_{2}}(\%)$ and $\mathrm{ER}_{\mathrm{scatt} / \mathrm{CO}}\left(\mathrm{Mm}^{-1} \mathrm{ppb}^{-1}\right)$ are the slope of the regression of $\mathrm{CO}$-to- $\mathrm{CO}_{2}$ and aerosol scattering (at $\left.550 \mathrm{~nm}\right)$ to $\mathrm{CO}$ for each plume, \pm standard error associated with the linear fit.

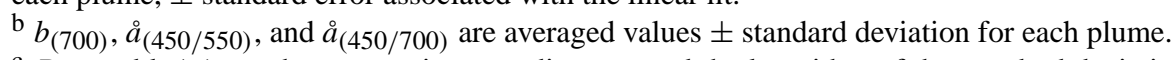

${ }^{c} D_{50}$ and $\ln (\sigma)$ are the geometric mean diameter and the logarithm of the standard deviation of the log-normal fitted size distributions, \pm standard error associated with the fit.

Table 5. Results from the Santa Lucia fire (SLF), a deforestation fire, situated south of the town of Vilhena, Rondônia, ca. $14.12^{\circ} \mathrm{S}, 60.17^{\circ} \mathrm{W}$.

\begin{tabular}{ccccccccc}
\hline Plume & $\mathrm{CE}$ & $\begin{array}{c}\mathrm{ER}_{\mathrm{CO} / \mathrm{CO}_{2}}{ }^{\mathrm{a}} \\
(\%)\end{array}$ & $\begin{array}{c}\mathrm{EF}_{\mathrm{CO}} \\
\left(\mathrm{g} \mathrm{kg}^{-1} \mathrm{dm}\right)\end{array}$ & $\begin{array}{c}\mathrm{ER}_{\mathrm{CN} / \mathrm{CO}^{\mathrm{a}}} \\
\left(\mathrm{cm}^{-3} \mathrm{ppm}^{-1}\right)\end{array}$ & $\begin{array}{c}\mathrm{EF}_{\mathrm{CN}} \\
\left(10^{15} \mathrm{~kg}^{-1} \mathrm{dm}\right)\end{array}$ & $\begin{array}{c}\mathrm{ER}_{\text {scatt/CO }}{ }^{\mathrm{a}} \\
\left(\mathrm{Mm}^{-1} \mathrm{ppb}^{-1}\right)\end{array}$ & $b_{(700)}{ }^{\mathrm{b}}$ & $\stackrel{\circ}{(450 / 700)}^{\mathrm{b}}$ \\
\hline Fresh plumes & $0.87-0.94$ & $4.2-12.4$ & $43-125$ & $9-35$ & $0.5-2$ & $0.17-0.40$ & $0.2-0.25$ & $1.88-2.30$ \\
In cloud & 0.94 & 5.2 & 52 & 19 & 1.1 & 0.51 & 0.19 & 2.20 \\
Detrained & 0.97 & 2.9 & 29 & 44 & 1.6 & 1.13 & 0.25 & 2.12 \\
\hline
\end{tabular}

${ }^{\mathrm{a}} \mathrm{ER}_{\mathrm{CO} / \mathrm{CO}_{2}}(\%)$ and $\mathrm{ER}_{\mathrm{scatt} / \mathrm{CO}}\left(\mathrm{Mm}^{-1} \mathrm{ppb}^{-1}\right)$ are the slope of the regression of $\mathrm{CO}$-to- $\mathrm{CO}_{2}$ and aerosol scattering (at $\left.550 \mathrm{~nm}\right)$ to $\mathrm{CO}$ for each plume.

${ }^{\mathrm{b}} b_{(700)}, \stackrel{\leftrightarrow}{a}_{(450 / 550)}$, and $\stackrel{\circ}{a}_{(450 / 700)}$ are averaged values \pm standard deviation for each plume.

\subsubsection{High altitude plumes}

As can be seen from Fig. 6, many plumes were encountered above the BL, so that the transport mechanism described above can be considered to be quite general. Numerous plumes (ca. 20 , and 14 with $\Delta \mathrm{CO}>100 \mathrm{ppb}$ ), which sometimes produced a distinct layer at this altitude discernable by eye, were measured at altitudes up to $4000-4300 \mathrm{~m}$ asl (which was about as high as the aircraft could fly). Even after having been transported to this altitude, these layers contained remarkably high levels of pollutants, with $\mathrm{CO}$ concentrations ranging $150-800 \mathrm{ppb}$. All of these plumes still yielded excellent regression coefficients from linear fits between $\mathrm{CN}$ and $\mathrm{CO}$. ER $\mathrm{CN} / \mathrm{CO}$ ranged $13-31 \mathrm{~cm}^{-3} \mathrm{ppb}^{-1}(21$ on average), while $\mathrm{ER}_{\mathrm{CO} / \mathrm{CO}_{2}}$ ranged $2.0-7.8 \%$ (5.1 on average). These values are in the range of what is typically found above the BL (Fig. 6). This further demonstrates how steady the number of particles per unit $\mathrm{CO}$ can be, even after such dramatic vertical transport, and therefore how little particle loss occurs during transport from the BL to FT. Moreover, since substantially higher losses would be expected to occur in precipitating clouds, these relatively large $\mathrm{ER}_{\mathrm{CN} / \mathrm{CO}} \mathrm{ob}-$ served for the high altitude plumes (and for detrained plumes in general) also imply that most of the transport to lower-mid tropospheric heights is through non-precipitating clouds, also suggesting suppression of rain due to heavy smoke pollution (Rosenfeld, 2000; Andreae et al., 2004).

\section{Conclusions}

In this study, we quantified the emission of aerosol particles from deforestation fires in the Amazon Basin, and shed some light on the processes affecting these aerosols during vertical transport and cloud processing. Our estimates for $\mathrm{ER}_{\mathrm{CN} / \mathrm{CO}}$ (14-32 $\mathrm{cm}^{-3} \mathrm{ppb}^{-1}$ for most of the plumes) for this type of fire fall in the range of what has been published previously for savanna fires (no previous data for deforestation fires are available for comparison). This highlights the relatively constant value of the number of particles emitted per unit $\mathrm{CO}$ from wild fires. This is a highly significant result, as $\mathrm{CO}$ is readily detected from space and is therefore the most commonly used and most readily validated tracer for biomass burning in atmospheric models. With a consistent ratio of aerosol particle and $\mathrm{CO}$ emissions for a broad range of fire types, parameterization of pyrogenic aerosols in large-scale climate and chemistry models is made much more reliable. 
The emission of particles was found to be dependent on the combustion efficiency of the fire. However, the overall variability in our data was dominated by the variability in emissions within each fire rather than by systematic differences between fires. This is attributed to very inhomogeneous and fast changing burning conditions of deforestation fires (fuel density, size, moisture, wind, etc.), in contrast to, e.g., savanna fires. This feature was confirmed by the $\mathrm{ER}_{\mathrm{CO} / \mathrm{CO}_{2}}$ of these fires, which varied over a very wide range for all plumes encountered overall, but also for specific fires. $\mathrm{EF}_{\mathrm{CO}}$, $\mathrm{EF}_{\mathrm{CN}}$, and $\mathrm{EF}_{\text {mass }}$ also covered a large range of values, yielding medians of $61 \mathrm{~g} \mathrm{~kg}^{-1} \mathrm{dm}, 1.5 \times 10^{15}$ particles kg ${ }^{-1} \mathrm{dm}$, and $4.5 \mathrm{~g} \mathrm{~kg}^{-1} \mathrm{dm}$, respectively.

It must be emphasized, however, that these "emission factors" pertain to the lofted plumes only, and do not represent all the material emitted by the fires. This complicates their applicability in larger-scale models. They are representative of the emissions that reach the FT in the region near the fires, and would correspond to what is seen near source regions by sensors that are weighted towards mid-and upper tropospheric concentrations, such as MOPPIT.

A large uncertainty in the analysis of the present dataset comes from the need to account for the RSC fraction of the emissions, which is missed during aircraft sampling. A tentative correction of the data resulted in median $\mathrm{EF}$ values of $90 \mathrm{~g} \mathrm{~kg}^{-1} \mathrm{dm}, 2.5 \times 10^{15}$ particles kg ${ }^{-1} \mathrm{dm}$, and $9.2 \mathrm{~g} \mathrm{~kg}^{-1}$ $\mathrm{dm}$ for $\mathrm{CO}$, aerosol number and mass, respectively, values that are 1.5, 1.7, and 2.1 times as large as the uncorrected data on average. These would be the EF values that would have to be used in large-scale models, which allow for the mixing of emissions released at different injection heights. This discrepancy underlines the urgency of studying RSC from tropical deforestation fires, for which there as no data available to date.

Another major output of this study is that the vertical transport, cloud processing, and subsequent release of smoke aerosols in the CDL and FT resulted in only a $20 \%$ reduction in particle number per ppb $\mathrm{CO}$, due primarily to in-cloud coagulation. These particles are released in large amounts into the CDL and the FT from non-precipitating clouds, and because of their increased size, they are even more efficient at scattering incoming radiation and acting as $\mathrm{CCN}$. This provides a reservoir of cloud-active particles in midtropospheric air, which can again affect cloud microphysical properties when it is re-entrained in growing convective clouds. Once in the mid- and upper troposphere, the smoke particles are subjected to long range transport, thereby influencing the FT chemistry, water cycle, and the radiation budget on a larger scale.

Acknowledgements. This work was carried out within the frame work of the Smoke, Aerosols, Clouds, Rainfall, and Climate (SMOCC) project, a European contribution to the Large-Scale Biosphere-Atmosphere Experiment in Amazonia (LBA). It was financially supported by the Max Planck Society (MPG) and the Environmental and Climate Program of the European Commission (contract $\mathrm{N}^{\circ}$ EVK2-CT-2001-00110 SMOCC).We are grateful for support of C. Brenninkmeijer (Max Planck Institute, Mainz, Germany) for performing the $\mathrm{CO}$ absolute calibration, J. von Jouanne (Max Planck Institute, Mainz, Germany), T. Germano (University of São Paulo, São Paulo, Brazil) and Carla Longo (Instituto Nacional do Pesquisas Especiais (INPE), Saõ Paulo, Brazil) for their technical support with the SMPS instrument, and the pilots of the INPE aircraft. The authors thank Ralf Gielow for supervising and the "Fundação de Amparo à Pesquisa do Estado de São Paulo" (FAPESP, São Paulo, Brazil) (project 98/00104-9) and PNW-USDA-FS (USA) (project 5147A) for financing the work at "Pista de Cabeça" (PCF). M. Cordova would like to thank FAPESP for her scholarship (project 99/04281-5). P. Artaxo, L. V. Rizzo, and L. V. Gatti acknowledge the Brazilian agencies FAPESP (97/11358-9) and MCT/CNPq (Instituto do Milênio LBA) for financial support.

Edited by: D. Rosenfeld

\section{References}

Andreae, M. O., Artaxo, P., Fischer, H., Freitas, S. R., Gregoire, J. M., Hansel, A., Hoor, P., Kormann, R., Krejci, R., Lange, L., Lelieveld, J., Lindinger, W., Longo, K., Peters, W., de Reus, M., Scheeren, B., Silva Dias, M. A. F., Ström, J., van Velthoven, P. F. J., and Williams, J.: Transport of biomass burning smoke to the upper troposphere by deep convection in the equatorial region, Geophys. Res. Lett., 28, 951-954, 2001.

Andreae, M. O., Atlas, E., Harris, G. W., Helas, G., deKock, A., Koppmann, R., Maenhaut, W., Mano, S., Pollock, W. H., Rudolph, J., Scharffe, D., Schebeske, G., and Welling, M.: Methyl halide emissions from savanna fires in southern Africa, J. Geophys. Res.-Atmos., 101, 23 603-23 613, 1996.

Andreae, M. O., Browell, E. V., Garstang, M., Gregory, G. L., Harriss, R. C., Hill, G. F., Jacob, D. J., Pereira, M. C., Sachse, G. W., Setzer, A. W., Dias, P. L. S., Talbot, R. W., Torres, A. L., and Wofsy, S. C.: Biomass-burning emissions and associated haze layers over Amazonia, J. Geophys. Res.-Atmos., 93, 1509-1527, 1988.

Andreae, M. O. and Merlet, P.: Emission of trace gases and aerosols from biomass burning, Global Biogeochem. Cycles, 15, 955966, 2001.

Andreae, M. O., Rosenfeld, D., Artaxo, P., Costa, A. A., Frank, G. P., Longo, K. M., and Silva-Dias, M. A. F.: Smoking rain clouds over the Amazon, Science, 303, 1337-1342, 2004.

Artaxo, P., Fernandes, E. T., Martins, J. V., Yamasoe, M. A., Hobbs, P. V., Maenhaut, W., Longo, K. M., and Castanho, A.: Largescale aerosol source apportionment in Amazonia, J. Geophys. Res.-Atmos., 103, 31 837-31 847, 1998.

Artaxo, P., Martins, J. V., Yamasoe, M. A., Procópio, A. S., Pauliquevis, T. M., Andreae, M. O., Guyon, P., Gatti, L. V., and Leal, A. M. G.: Physical and chemical properties of aerosols in the wet and dry season in Rondônia, Amazonia, J. Geophys. Res.-Atmos., 107, 8081, doi:8010.1029/2001JD000666, 2002.

Baron, P. A.: Aerosol calculator (computer spreadsheet), TSI, Inc., St. Paul, 2001.

Bertschi, I., Yokelson, R. J., Ward, D. E., Babbitt, R. E., Susott, R. A., Goode, J. G., and Hao, W. M.: Trace gas and particle emissions from fires in large diameter and belowground biomass 
fuels, J. Geophys. Res., 108, 8472, doi:10.1029/2002JD002100, 2003.

Brenninkmeijer, C. A. M., Koeppel, C., Rockmann, T., Scharffe, D. S., Braunlich, M., and Gros, V.: Absolute measurement of the abundance of atmospheric carbon monoxide, J. Geophys. Res.Atmos., 106, 10 003-10 010, 2001.

Chand, D., Guyon, P., Artaxo, P., Schmid, O., Frank, G. P., Rizzo, L. V., Mayol-Bracero, O. L., Gatti, L. V., Andreae, M. O.: Optical and physical properties of aerosols in the boundary layer and free troposphere over the Amazon Basin during the biomass burning season, Atmos. Chem. Phys. Discuss., 5, 4373-4406, 2005,

\section{SRef-ID: 1680-7375/acpd/2005-5-4373.}

Delmas, R., Lacaux, J. P., and Brocard, D.: Determination of biomass burning emission factors: Methods and results, Environ. Monit. Assess., 38, 181-204, 1995.

Eck, T. F., Holben, B. N., Reid, J. S., O’Neill, N. T., Schafer, J. S., Dubovik, O., Smirnov, A., Yamasoe, M. A., and Artaxo, P.: High aerosol optical depth biomass burning events: A comparison of optical properties for different source regions, Geophys. Res. Lett., 30, 2035, doi:10.1029/2003GL017861, 2003.

Ferek, R. J., Reid, J. S., Hobbs, P. V., Blake, D. R., and Liousse, C.: Emission factors of hydrocarbons, halocarbons, trace gases and particles from biomass burning in Brazil, J. Geophys. Res.Atmos., 103, 32 107-32 118, 1998.

Fisch, G., Tota, J., Machado, L. A. T., Silva Dias, M. A. F., Lyra, R. F. d. F., Nobre, C. A., Dolman, A. J., and Gash, J. H. C.: The convective boundary layer over pasture site and forest in Amazonia, Theoretical and Applied Climatology, 78, 47-59, 2004.

Freitas, S. R., Longo, K. M., Dias, M. A. F. S., Dias, P. L. S., Chatfield, R., Prins, E., Artaxo, P., and Recuero, F. S.: Monitoring the transport of biomass burning emissions in South America, Environmental Fluid Mechanics, 5, 135-167, 2005.

Gash, J. H. C., Nobre, C. A., Roberts, J. M., and Victoria, R. L.: Amazonian deforestation and climate, John Wiley \& Sons Ltd, Chichester, England, 1996.

Greenberg, J. P., Zimmerman, P. R., Heidt, L., and Pollock, W.: Hydrocarbon and carbon-monoxide emissions from biomass burning in Brazil, J. Geophys. Res.-Atmos., 89, 1350-1354, 1984.

Guyon, P., Graham, B., Beck, J., Boucher, O., Gerasopoulos, E., Mayol-Bracero, O. L., Roberts, G. C., Artaxo, P., and Andreae, M. O.: Physical properties and concentration of aerosol particles over the Amazon tropical forest during background and biomass burning conditions, Atmos. Chem. Phys., 3, 951-967, 2003, SRef-ID: 1680-7324/acp/2003-3-951.

Hobbs, P. V., Sinha, P., Yokelson, R. J., Christian, T. J., Blake, D. R., Gao, S., Kirchstetter, T. W., Novakov, T., and Pilewskie, P.: Evolution of gases and particles from a savanna fire in South Africa, J. Geophys. Res., 108, 8485, doi:10.1029/2002JD002352, 2003.

IPCC: Climate change 2001: The third assessment report to the intergovernmental panel on climate change, Cambridge University Press, Cambridge, United kingdom, and New York, NY, USA, 2001.

Kauffman, J. B., Cummings, D. L., and Ward, D. E.: Fire in the Brazilian Amazon 2. Biomass, nutrient pools and losses in cattle pastures, Oecologia, 113, 415-427, 1998.

Kaufman, Y. J., Hobbs, P. V., Kirchhoff, V., Artaxo, P., Remer, L. A., Holben, B. N., King, M. D., Ward, D. E., Prins, E. M., Longo, K. M., Mattos, L. F., Nobre, C. A., Spinhirne, J. D., Ji, Q., Thompson, A. M., Gleason, J. F., Christopher, S. A., and
Tsay, S. C.: Smoke, Clouds, and Radiation - Brazil (SCAR-B) experiment, J. Geophys. Res.-Atmos., 103, 31 783-31 808, 1998.

Le Canut, P., Andreae, M. O., Harris, G. W., Wienhold, F. G., and Zenker, T.: Airborne studies of emissions from savanna fires in southern Africa .1. Aerosol emissions measured with a laser optical particle counter, J. Geophys. Res.-Atmos., 101, 23615 $23630,1996$.

Liousse, C., Cachier, H., Grégoire, J. M., Penner, J., Lavoué, D., Hobbs, P., Scholes, M., Barbosa, P., Andreae, M. O., and Artaxo, P.: Deriving global quantitative estimates for spatial and temporal distributions of biomass burning emissions, in: Emissions of trace gases and aerosols into the atmosphere, edited by: Granier, C., Artaxo, P., and Reeves, C., Kluwer Academic Publishers, London, 2004.

Lloyd, J., Francey, R. J., Mollicone, D., Raupach, M. R., Sogachev, A., Arneth, A., Byers, J. N., Kelliher, F. M., Rebmann, C., Valentini, R., Wong, S. C., Bauer, G., and Schulze, E. D.: Vertical profiles, boundary layer budgets, and regional flux estimates for $\mathrm{CO}_{2}$ and its $\mathrm{C}-13 / \mathrm{C}-12$ ratio and for water vapor above a forest/bog mosaic in central Siberia, Global Biogeoch. Cycles, 15, 267-284, 2001.

Lobert, J. M., Sharffe, D. H., Hao, W. M., Kuhlbusch, T. A. J., Seuwen, R., Warneck, P., and Crutzen, P. J.: Experimental evaluation of biomass burning emissions: Nitrogen and Carbon containing compounds, in: Global Biomass Burning: Atmospheric, Climatic, and Biospheric Implications, edited by: Levine, J. S., pp. 289-304, MIT Press, Cambridge, Mass., 1991.

Martins, J. V., Artaxo, P., Liousse, C., Reid, J. S., Hobbs, P. V., and Kaufman, Y. J.: Effects of black carbon content, particle size, and mixing on light absorption by aerosols from biomass burning in Brazil, J. Geophys. Res.-Atmos., 103, 32 041-32 050, 1998.

Mauzerall, D. L., Logan, J. A., Jacob, D. J., Anderson, B. E., Blake, D. R., Bradshaw, J. D., Heikes, B., Sachse, G. W., Singh, H., and Talbot, B.: Photochemistry in biomass burning plumes and implications for tropospheric ozone over the tropical South Atlantic (vol 103, p. 8401, 1998), J. Geophys. Res.-Atmos., 103, 19281-19282, 1998.

Nobre, C. A., Fisch, G., Rocha, H. R. d., Lyra, R. F. d. F., Rocha, E. P. d., Costa, A. C. L. d., and Ubarana, V. N.: Observations of the atmospheric boundary layer in Rondônia, in: Amazonian deforestation and climate, edited by: Gash, J. H. C., Nobre, C. A., Roberts, J. M., and Victoria, R. L., pp. 413-424, John Wiley \& Sons Ltd, Chichester, England, 1996.

Pickering, K. E., Thompson, A. M., Wang, Y. S., Tao, W. K., McNamara, D. P., Kirchhoff, V., Heikes, B. G., Sachse, G. W., Bradshaw, J. D., Gregory, G. L., and Blake, D. R.: Convective transport of biomass burning emissions over Brazil during TRACE A, J. Geophys. Res.-Atmos., 101, 23 993-24 012, 1996.

Prasad, V. K., Gupta, P. K., Sharma, C., Sarkar, A. K., Kant, Y., Badarinath, K. V. S., Rajagopal, T., and Mitra, A. P.: NOx emissions from biomass burning of shifting cultivation areas from tropical deciduous forests of India - Estimates from groundbased measurements, Atmos. Environ., 34, 3271-3280, 2000.

Prins, E. M., Feltz, J. M., Menzel, W. P., and Ward, D. E.: An overview of GOES- 8 diurnal fire and smoke results for SCAR-B and 1995 fire season in South America, J. Geophys. Res.-Atmos., 103, 31 821-31 835, 1998.

Procópio, A. S., Artaxo, P., Kaufman, Y. J., Remer, L. A., Schafer, J. S., and Holben, B. N.: Multiyear analysis of amazonian biomass 
burning smoke radiative forcing of climate, Geophys. Res. Lett., 31, L03108, doi:10.1029/2003GL018646, 2004.

Reid, J. S. and Hobbs, P. V.: Physical and optical properties of young smoke from individual biomass fires in Brazil, J. Geophys. Res.-Atmos., 103, 32 013-32 030, 1998.

Reid, J. S., Hobbs, P. V., Ferek, R. J., Blake, D. R., Martins, J. V., Dunlap, M. R., and Liousse, C.: Physical, chemical, and optical properties of regional hazes dominated by smoke in Brazil, J. Geophys. Res.-Atmos., 103, 32 059-32 080, 1998.

Rosenfeld, D.: Suppression of rain and snow by urban and industrial air pollution, Science, 287, 1793-1796, 2000.

Schafer, J. S., Eck, T. F., Holben, B. N., Artaxo, P., Yamasoe, M. A., and Procopio, A. S.: Observed reductions of total solar irradiance by biomass- burning aerosols in the Brazilian Amazon and Zambian Savanna, Geophys. Res. Lett., 29, 1823, doi:10.1029/2001GL014309, 2002.

Ward, D. E., Hao, W. M., Susott, R. A., Babbitt, R. E., Shea, R. W., Kauffman, J. B., and Justice, C. O.: Effect of fuel composition on combustion efficiency and emission factors for African savanna ecosystems, J. Geophys. Res.-Atmos., 101, 23 569$23576,1996$.
Ward, D. E., Setzer, A. W., Kaufman, Y. J., and Rasmussen, R. A.: Characteristics of smoke emissions from biomass fires of the Amazon region - BASE-A experiment, in: Global Biomass Burning: Atmospheric, Climatic, and Biospheric Implications, edited by: Levine, J. S., pp. 394-402, MIT Press, Cambridge, Mass., 1991.

Ward, D. E., Susott, R. A., Kauffman, J. B., Babbitt, R. E., Cummings, D. L., Dias, B., Holben, B. N., Kaufman, Y. J., Rasmussen, R. A., and Setzer, A. W.: Smoke and fire Characteristics for cerrado and deforestation burns in Brazil - Base-B experiment, J. Geophys. Res.-Atmos., 97, 14 601-14 619, 1992.

Yokelson, R. J., Bertschi, I. T., Christian, T. J., Hobbs, P. V., Ward, D. E., and Hao, W. M.: Trace gas measurements in nascent, aged, and cloud-processed smoke from African savanna fires by airborne Fourier transform infrared spectroscopy (AFTIR), J. Geophys. Res.-Atmos., 108, 8478, doi:10.1029/2002JD002322, 2003. 